\title{
Pencak Silat Tournament Information System
}

Sistem Informasi Kejuaraan Pencak Silat

\section{Ari Kusuma Wardana1, Eko Aribowo}

${ }^{1}$ Informatika, Universitas PGRI Yogyakarta, Indonesia

2 Teknik Informatika, Universitas Ahmad Dahlan, Indonesia

${ }^{1}$ ari@upy.ac.id, 2*ekoab@tif.uad.ac.id

\section{Informasi Artikel}

Received: 30 December 2020

Revised: 9 February 2021

Accepted: 23 February 2021

Published: 28 February 2021

Keywords: information system;

pencak silat; IPSI

Kata kunci: sistem informasi; pencak silat; IPSI

\begin{abstract}
Purpose: This research was conducted to help manage the implementation of the pencak silat championship. So that the championship can run in an orderly and professional manner.

Design/methodology/approach: This research went through several stages, starting from data collection, system requirements analysis, design, implementation, and system testing.

Findings/result: Website-based information system for pencak silat tournament.

Originality/value/state of the art: Pencak silat is a martial arts rich in techniques, benefits, and carries noble values that should be preserved as the Indonesian nation's successor. To preserve the existence of pencak silat in Indonesia, various pencak silat competitions were held in several cities in Indonesia. In the championship implementation, several things can disrupt the course of the matches. Of course, it will make the championship unprofessional. For this reason, along with the development of science and technology, a system was created that would help manage the implementation of the pencak silat championship so that the championship can run in an orderly and professional manner.
\end{abstract}

Abstrak
Tujuan: Penelitian ini dilakukan untuk membantu
mengelola penyelenggaraan kejuaraan pencak silat.
Sehingga kejuaraan dapat berjalan dengan tertib dan
profesional.


Perancangan/metode/pendekatan: Penelitian ini melalui beberapa tahap, dimulai dari pengumpulan data, analisis kebutuhan sistem, perancangan, implementasi, dan pengujian sistem.

Hasil: Sistem informasi kejuaraan pencak silat berbasis website.

Keaslian / state of the art: Pencak silat adalah salah satu seni bela diri yang kaya akan teknik, manfaat, dan membawa nilai-nilai luhur yang sudah seharusnya dilestarikan sebagai penerus bangsa Indonesia. Sebagai upaya melestarikan keberadaan pencak silat di Indonesia, berbagai kejuaraan pencak silat digelar di beberapa kota di Indonesia. Dalam pelaksanaan kejuaraan, ada beberapa hal yang berpotensi mengacaukan jalannya pertandingan. Hal ini tentu akan membuat kejuaraan menjadi tidak profesional. Untuk itu, seiring perkembangan ilmu pengetahuan dan teknologi, maka dibuatlah sebuah sebuah sistem yang akan membantu mengelola penyelenggaraan kejuaraan pencak silat. Sehingga kejuaraan dapat berjalan dengan tertib dan profesional.

\section{Pendahuluan}

Pencak silat merupakan seni bela diri yang berasal dari nenek moyang bangsa Indonesia. Sejak zaman dahulu, pencak silat sudah membudaya di Indonesia [1]. Pencak silat lahir dari budaya bangsa dalam hal membela diri dan mempertahankan diri [2]. Pencak silat kaya akan teknik, manfaat, dan membawa nilai-nilai luhur yang sudah semestinya dilestarikan sebagai penerus bangsa Indonesia [3] [4]. Sebagai metode filosofis yang mengajarkan pendidikan spiritual serta fisik, pencak silat membantu para peminatnya untuk menghayati nilai-nilai moral yang luhur di dalamnya [5]. Organisasi pencak silat yang menaungi seluruh aliran pencak silat yang ada di Indonesia diberi nama Ikatan Pencak Silat Indonesia atau yang lebih dikenal dengan IPSI [6]. Hampir setiap tahunnya berbagai ajang bergengsi kejuaraan pertandingan pencak silat diselenggarakan di berbagai kota di Indonesia. Penyelenggaraan kejuaraan pertandingan pencak silat dilakukan dalam rangka menjaga dan melestarikan pencak silat di Indonesia. Secara resmi pencak silat sudah masuk sebagai cabang olah raga dalam pertandingan internasional, dalam hal ini dipertandingkan dalam ajang SEA Games [6].

Pada prinsipnya setiap penyelenggaraan kejuaraan pencak silat harus dikelola secara tertib dan profesional. Hal ini dikarenakan biasanya kejuaraan pencak silat sangat rawan protes. Sistem pertandingan pencak silat jauh lebih rumit dibandingkan penyelenggaraan kejuaraan olahraga yang lain karena dalam setiap kejuaraan pasti diikuti banyak sekali peserta dan mempertandingkan hingga ratusan partai. Apabila panitia pelaksana tidak cermat dapat menimbulkan kesalahan fatal yang dapat mengacaukan jalannya kejuaraan. Kesalahan awal dalam pendaftaran peserta dapat mengakibatkan pesilat tidak masuk dalam jadwal pertandingan. Proses pengelolaan data yang dilakukan secara manual sehingga potensi human error cukup tinggi. Biasanya selalu ada kasus peserta lupa tidak dijadwalkan bertanding, atau salah mengatur 
jadwal pertandingan, dan bermacam human error akibat kelelahan panitia pertandingan. Sistem penilaian pertandingan yang dilakukan dewan juri masih manual, sehingga pemberian nilai untuk peserta pertandingan tidak dapat dihitung secara cepat.

Peranan sistem informasi pada suatu organisasi tidak dapat diragukan lagi. Keunggulan kompetitif, yang berarti bahwa suatu perusahaan bisa bersaing dengan perusahaan lain dengan mempergunakan sistem informasi [7]. Berbicara mengenai dunia sistem informasi, terdapat banyak sekali model sistem informasi yang bertujuan memberikan berbagai macam informasi. Sistem informasi membuat seseorang dapat dengan cepat memperoleh informasi yang diinginkan [8]. Kemajuan bidang teknologi dan informasi khususnya sistem informasi memungkinkan dapat digunakan untuk membantu kejuaraan pencak silat dalam meminimalisasi dan mengeliminasi kesalahan fatal yang dapat mengacaukan jalannya kejuaraan.

Tuntutan bekerja secara profesional untuk mengeliminasi setiap potensi kesalahan dan agar kejuaraan pencak silat berjalan dengan baik sesuai harapan, maka dibutuhkan sebuah alat bantu dalam pengelolaan pelaksanaan kejuaraan pencak silat, baik secara aspek administrasi pertandingan maupun penilaian pertandingan. Berdasarkan hal tersebut, maka perlu dibuat sebuah sistem informasi pertandingan pencak silat.

Tinjauan pustaka penelitian ini menggunakan referensi dari penelitian-penelitian terdahulu yang diambil menurut keselarasan dengan penelitian yang dilakukan. Penelitian yang pertama adalah penelitian tentang perancangan website $e$-commerce untuk menjual alat olahraga pencak silat [9]. Penelitian tersebut membuat sebuah website $e$ - commerce dengan keperluan untuk penjualan alat olahraga pencak silat. Metode pengembangan sistem yang digunakan pada penelitian ini menggunakan metode waterfall. Hasil akhir dari penelitian adalah website penjualan alat olahraga khususnya pencak silat. Dimana website tersebut dapat menghubungkan secara langsung antara penjual dan pembeli dengan menggunakan jaringan internet, sehingga dapat memudahkan pengguna mencari alat olahraga pencak silat yang dibutuhkan.

Selanjutnya adalah penelitian tentang membuat sistem pendaftaran dan edukasi pencak silat berbasis website [10]. Sistem yang dibangun adalah sebuah sistem berbasis website dengan menggunakan framework codeigniter. Sistem ini dibuat dengan tujuan mempercepat kerja pengurus sekretariat dalam mengolah data pendaftaran dan edukasi pada perguruan pencak silat Budi Asih. Satu tahun setelah penelitian Ghozali dkk, Qomariah melakukan penelitian tentang sistem pendukung keputusan untuk menyeleksi atlet pencak silat [11]. Qomariah melakukan penelitian sistem pendukung keputusan dengan membandingkan dua buah metode, yaitu metode SAW (Simple Additive Weighting) dengan MFEP (Multi Factor Evaluation Process). Ditahun yang sama, Haris melakukan penelitian tentang pencak silat. Haris meneliti tentang bagaimana merancang sebuah sistem panduan pencak silat berbasis web mobile [12]. Metode pengembangan sistem yang dipakai Haris, sama seperti yang digunakan oleh Widodo [9], yaitu sama-sama mengunakan metode waterfall. Haris membuat sistem tersebut dengan tujuan untuk memberikan informasi-informasi kepada anggota pencak silat persaudaraan setia hati terate palangkaraya secara online.

Kesamaan antara penelitian sistem informasi kejuaraan pencak silat dengan penelitian yang menjadi tinjauan pustaka pada penelitian ini adalah sama-sama mengkaji tentang sistem yang berkaitan dengan pencak silat. Selain itu, kesamaan lainnya pada penelitian ini dengan penelitian sebelumnya adalah metode pengembangan sistem yang digunakan sama-sama 
menggunakan metode waterfall. Waterfall merupakan salah satu model system development life cycle yang sering digunakan di dalam pengembangan sistem informasi [13], metode ini menyediakan pendekatan alur hidup perangkat lunak secara terurut [14]. Perencanaan sistem, analisa kebutuhan, desain, penulisan program, pengujian, dan perawatan sistem merupakan tahapan yang ada di dalam metode waterfall [15]. Kesamaan yang terakhir antara penelitian ini dengan beberapa penelitian sebelumnya adalah sama-sama menggunakan bahasa pemrograman berbasis web. Aktifitas-aktifitas yang masih dilakukan secara manual, dapat ditangani oleh aplikasi yang berbasis web secara lebih efisien dan efektif [16]. Aplikasi berbasis web memungkinkan data dan informasi dapat diakses dari jarak yang jauh secara tepat, akurat dan efisien [17].

Perbedaan antara penelitian sistem informasi kejuaraan pencak silat dengan penelitian yang menjadi tinjauan pustaka pada penelitian ini adalah sistem yang dibangun adalah sistem yang dibangun untuk menyelesaikan permasalahan dalam penyelenggaraan suatu kejuaraan pencak silat. Sehingga dengan sistem informasi ini, kejuaraan dapat berjalan dengan baik dan profesional.

\section{Metode Penelitian}

\subsection{Metode Pengumpulan Data}

Metode pengumpulan data pada penelitian ini dilakukan dengan tiga cara, yaitu observasi, wawancara, dan studi pustaka. Pengamatan secara langsung atau observasi dilakukan pada saat Pimda 02 Tapak Suci Bantul Yogyakarta menyelenggarakan kejuaraan pertandingan pencak silat tapak suci. Wawancara dilakukan secara langsung kepada panitia penyelenggara kejuaraan pencak silat di Pimda 02 Tapak Suci Bantul. Dalam studi pustaka peneliti melakukan pengamatan dan mempelajari dari buku-buku, mencari data-data di internet yang berhubungan dengan penelitian yang dilakukan.

\subsection{Analisis Kebutuhan Sistem}

Kegiatan dalam tahap ini adalah menganalisis kebutuhan untuk membangun sistem informasi kejuaraan pencak silat. Proses analisis mengacu terhadap hasil observasi dan wawancara yang sudah dilakukan dengan pihak-pihak yang biasa menyelenggaraan kejuaraan pencak silat, dalam hal ini adalah Pimda 02 Tapak Suci Bantul Yogyakarta.

\subsection{Perancangan}

Merancang proses menggunakan data flow diagram (DFD) yang meliputi pembuatan kamus data, diagram konteks dan pembuatan DFD. Selain perancangan dengan menggunakan DFD, dilakukan juga perancangan basis data dan antarmuka sistem yang akan dibangun. Pada tahap perancangan proses, terdapat tiga proses yaitu pembuatan kamus data, diagram konteks dan pembuatan DFD. Pada tahap perancangan basis data, terdapat empat proses yaitu pembuatan konseptual awal, entity relationship diagram, mapping table, dan pembuatan struktur tabel. Pada tahap perancangan antarmuka, dibuatlah sebuah rancangan antarmuka dari sistem kejuaraan pencak silat.

\subsection{Implementasi}

Pembuatan sistem informasi menggunakan bahasa pemrograman PHP dan menggunakan MySQL untuk mengelola data di dalam sistem. Tahap ini adalah tahap implementasi hasil 
perancangan ke dalam baris-baris kode program yang dapat dimengerti oleh mesin atau komputer.

\subsection{Pengujian Sistem}

Metode pengujian sistem pada penelitian ini adalah menggunakan metode black box testing, yaitu sebuah metode pengujian yang terfokus pada fungsi yang terdapat di dalam sistem [18]. Kerja dari black box testing lebih berfokus pada informasi domain dan mengabaikan struktur kontrol [19].

\section{Hasil dan Pembahasan}

Hasil dari penelitian ini adalah sebuah sistem informasi kejuaraan pencak silat yang menggunakan bahasa pemrograman PHP. Bahasa pemrograman yang berjalan dalam sebuah web server salah satunya adalah PHP [20]. Terdapat tiga pengguna di dalam sistem ini, yaitu admin, dewan juri, dan ketua. Pihak pertama yaitu admin yang menginginkan proses manajemen penyelenggaraan kejuaraan pencak silat yang tersusun secara rapi dan tertib. Pihak pengguna kedua yaitu pihak dewan juri yang memerlukan media untuk memberikan penilaian terhadap pesilat yang bertanding menggunakan sistem yang telah terkomputerisasi. Pihak ketiga yaitu ketua yang menginginkan informasi seputar pertandingan dan memperoleh laporan dari sebuah kejuaraan pertandingan pencak silat. Sebelum mengimplementasikan sistem kedalam bahasa pemrograman, perancangan sistem dilakukan terlebih dahulu.

Perancangan sistem pada penelitian ini salah satunya menggunakan data flow diagram (DFD), DFD pada penelitian ini dapat dilihat pada Gambar 1. Gambar 1 merupakan DFD level 0, di mana DFD level 0 adalah diagram tingkat atas, yaitu yang paling tidak detail dari suatu sistem informasi. DFD level 0 menempatkan sistem dalam konteks yang berguna sebagai identifikasi semua input dan output yang terlibat dalam sistem. DFD level 0 selalu mengandung satu proses saja yang mewakili seluruh sistem. Gambar 1 menggambarkan sistem untuk pertama kalinya secara garis besar. Proses ini mewakili seluruh proses yang terjadi dari keseluruhan proses dalam sistem yang akan menjadi unsur yang akan dipecah-pecah lagi menjadi diagram arus data yang lebih detail. 


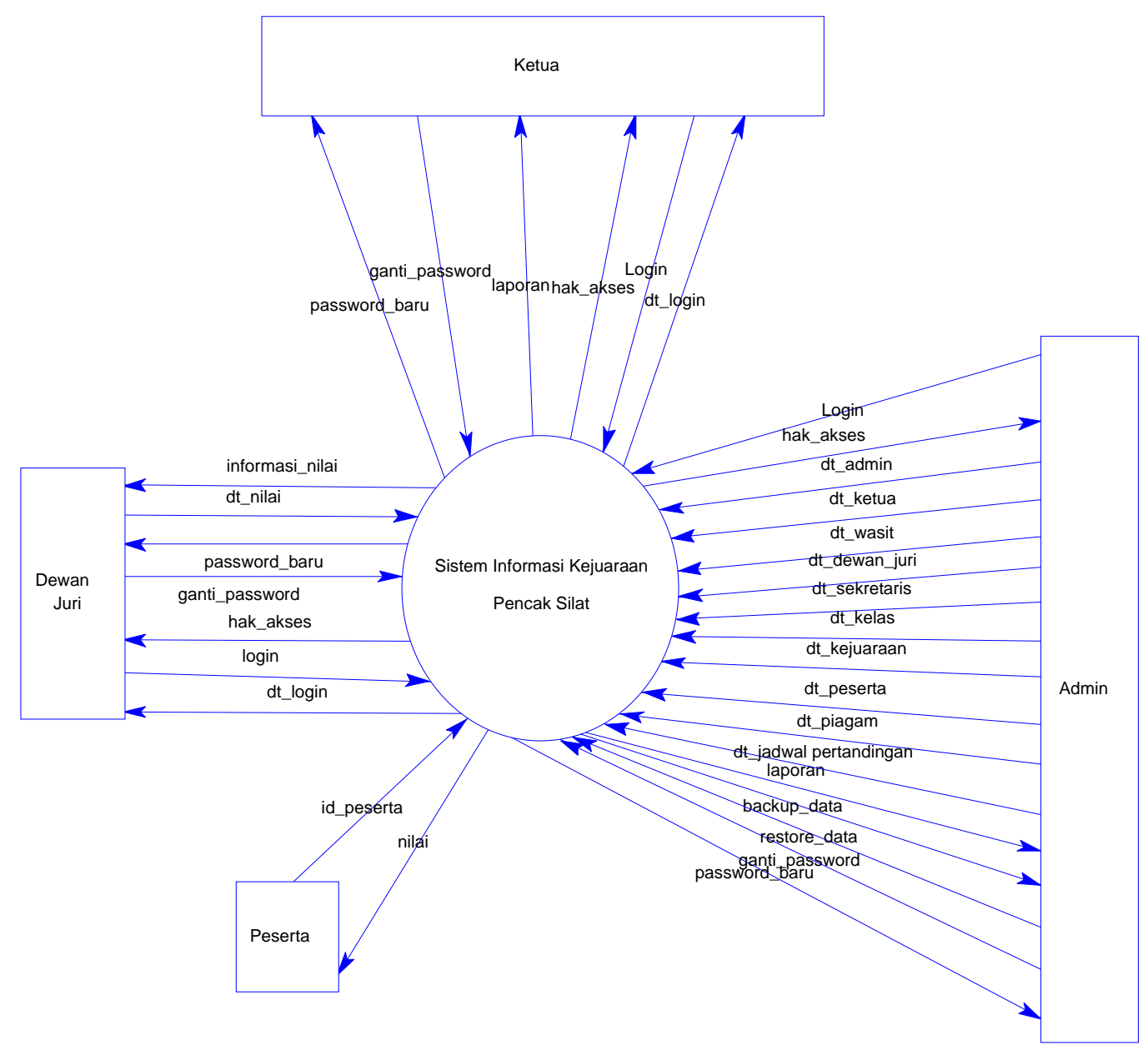

Gambar 1. DFD Level 0

Untuk mengakases sistem, pengguna harus melewati proses login terlebih dahulu, login merupakan suatu fitur yang pertama dilihat oleh pengguna maupun pengelola ketika akan mengakses sistem [21]. Tampilan menu login pada sistem ini dapat dilihat pada Gambar 2.

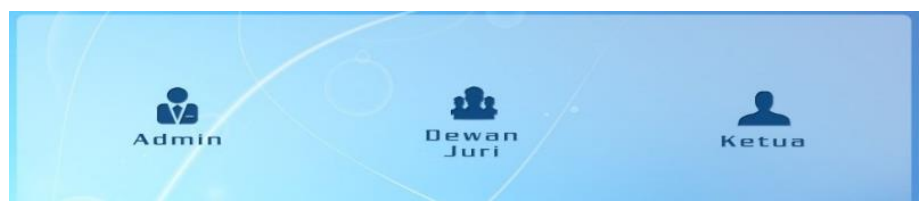

Gambar 2. Form Menu Login

Gambar 2 muncul ketika pertama kali membuka sistem informasi, panitia (admin, dewan juri dan ketua) harus memilih status login terlebih dahulu sebelum login ke dalam sistem. Menu utama setelah login akan berbeda-beda. Tergantung status login yang dipilih oleh panitia. Menu utama yang diperoleh panitia dengan status admin akan lebih banyak, dibandingkan dewan juri dan ketua panitia kejuaraan pencak silat. Hal ini dikarenakan admin bertugas mengatur jalannya pertandingan, mengatur jadwal pertandingan, mengatur jadwal wasit pertandingan, dan lainlain. Tampilan menu utama untuk admin dapat dilihat pada Gambar 3. 
Master $\mid$ Setting Pertandingan $\mid$ Record Nilai $\mid$ Laporan $\mid$ Setting $\mid$ Ari Kusuma Wardana

\section{Selamat Datang}

Gambar 3. Form Menu Utama Admin

Admin dapat mengelola mengolah seluruh data kelas seperti tambah kelas, edit data kelas, dan menghapus data kelas dalam suatu kejuaraan melalui form menu master data kelas. Gambar 4 merupakan gambar form menu master data kelas.

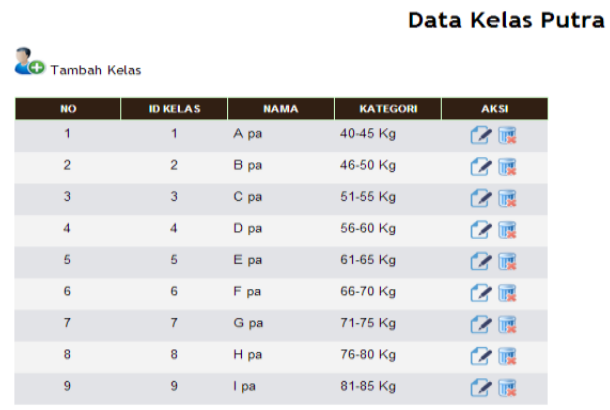

Gambar 4. Form Menu Master Data Kelas

Admin mengelola seluruh data kejuaraan seperti tambah kejuaraan, edit data kejuaraan, dan menghapus data kejuaraan melalui form menu master data kejuaraan. Form menu master data kejuaraan pada penelitian ini dapat dilihat pada Gambar 5.

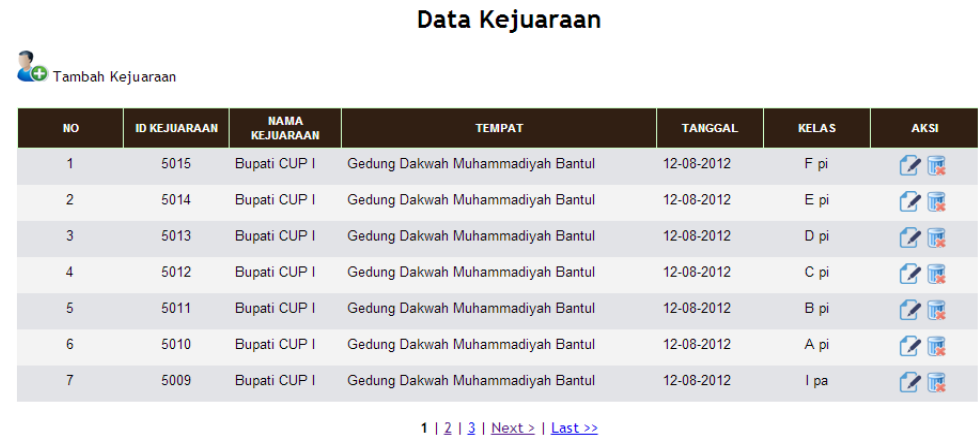

Gambar 5. Form Menu Master Data Kejuaraan

Admin mengelola seluruh data peserta seperti tambah peserta, edit data peserta, lihat detail data peserta, dan menghapus data peserta melalui form menu master data peserta. Form menu master data peserta dapat dilihat pada Gambar 6. 


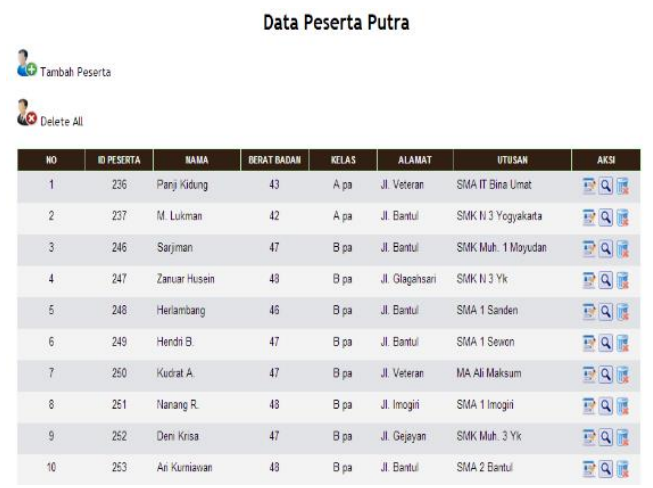

Gambar 6. Form Menu Master Data Peserta

Admin dapat melakukan pengaturan dan mengelola kejuaraan melalui form setting pertandingan seperti yang tertera pada Gambar 7. Form pada Gambar 7 digunakan untuk mengolah seluruh data pertandingan seperti tambah pertandingan yang mempertemukan peserta yang satu dengan peserta yang lainnya, lihat detail pertandingan, dan hapus pertandingan.

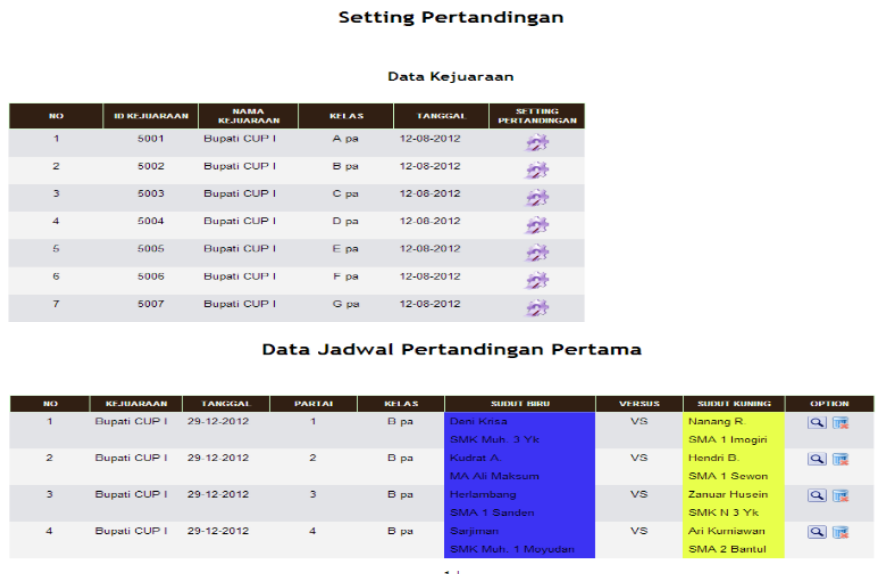

Gambar 7. Form Setting Pertandingan

Dewan juri menginputkan penilaian kepada para peserta yang bertanding melalui form input nilai. Form ini hanya tersedia untuk pemakai sistem dengan status sebagai dewan juri. Tampilan form input nilai seperti yang tertera pada Gambar 8. 


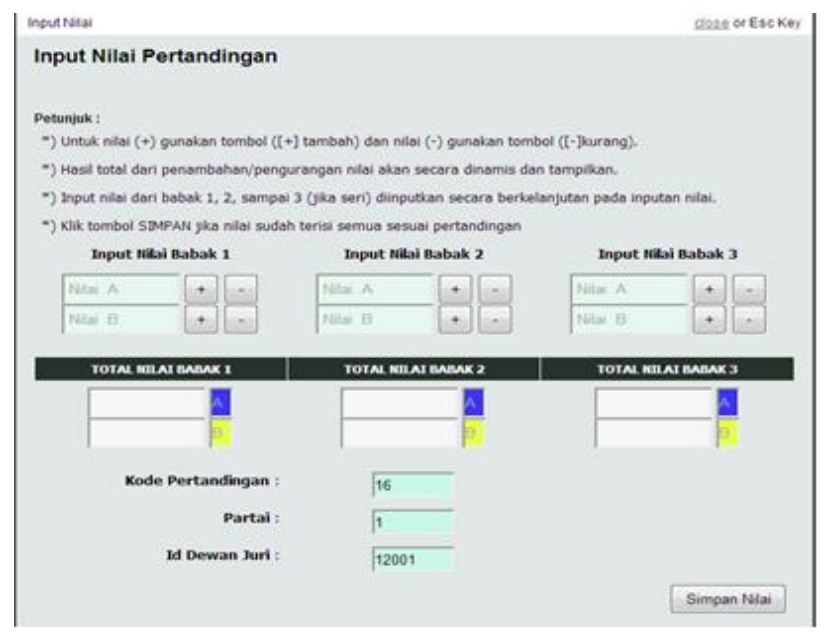

Gambar 8. Form Input Nilai

Admin dan ketua kejuaraan dapat melihat hasil penilaian pertandingan dari semua juri melalui form menu laporan pertandingan. Form ini juga digunakan untuk mengelola seluruh laporan pertandingan seperti mencetak laporan hasil pertandingan. Tampilan form menu laporan pertandingan dapat dilihat pada Gambar 9.

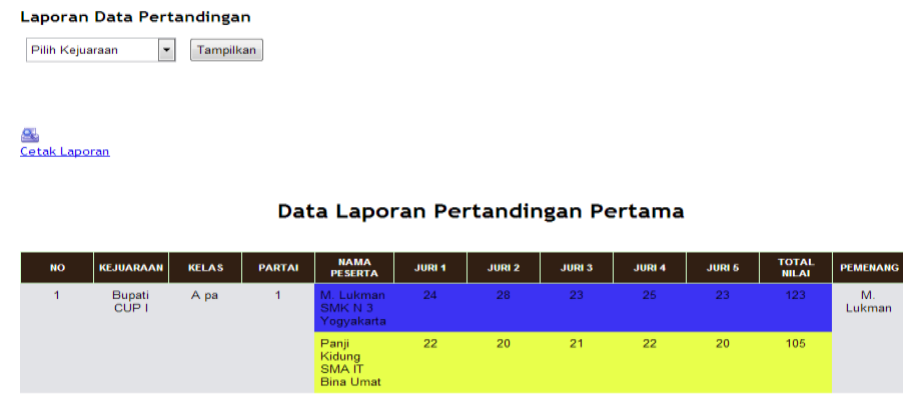

Gambar 9. Form Menu Laporan Pertandingan

Admin dan ketua kejuaraan dapat melihat jadwal keseluruhan pertandingan melalui form menu laporan jadwal pertandingan. Form ini juga digunakan untuk mengelola seluruh laporan jadwal pertandingan seperti mencetak laporan jadwal pertandingan. Tampilan form menu laporan jadwal pertandingan dapat dilihat pada Gambar 10. 


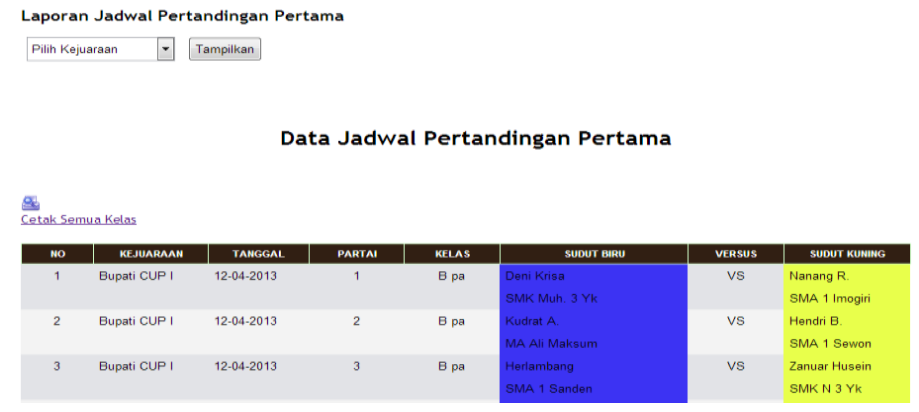

Gambar 10. Form Menu Laporan Jadwal Pertandingan

Admin dan ketua kejuaraan dapat melihat peserta yang memperoleh juara dalam suatu kejuaraan di setiap kelasnya melalui form menu laporan kejuaraan. Form ini juga digunakan untuk mengelola seluruh laporan kejuaraan seperti mencetak laporan kejuaraan. Tampilan form menu laporan kejuaraan dapat dilihat pada Gambar 11.

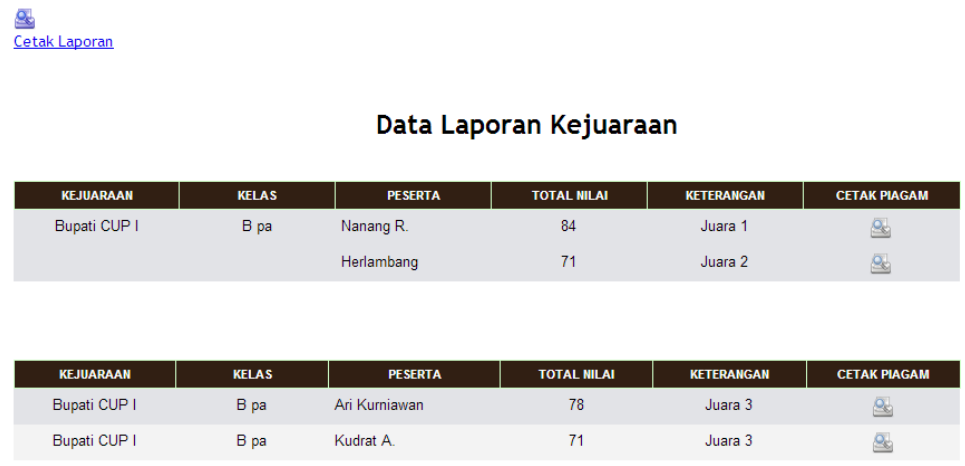

Gambar 11. Form Menu Laporan Kejuaraan

Dari hasil uji sistem, user interface mudah dimengerti untuk berkomunikasi antara user dengan sistem. Fungsi-fungsi dasar sistem dalam mengelola data seperti menambah, mengubah, dan menghapus baik data admin, ketua pertandingan, dewan juri, wasit, sekretaris, kelas, kejuaraan, peserta, jadwal pertandingan, dan nilai peserta dapat berjalan dengan baik. Hasil uji sistem ini membuktikan bahwa sistem informasi kejuaraan pertandingan pencak silat sudah dapat digunakan sebagai solusi dari potensi kesalahan pengelolaan penyelenggaraan pertandingan.

\section{Kesimpulan dan Saran}

Berdasarkan penelitian yang sudah dilakukan tentang Sistem Informasi Kejuaraan Pencak Silat, dapat disimpulkan bahwa sistem Informasi Kejuaraan Pencak Silat dapat melakukan penyimpanan data admin, ketua pertandingan, dewan juri, wasit, sekretaris, kelas, kejuaraan, peserta, jadwal pertandingan, dan nilai peserta dengan baik. Selain itu, sistem dapat melakukan penjadwalan pertandingan dengan baik sehingga kasus peserta lupa tidak dijadwalkan bertanding, atau terbalik mengatur jadwal pertandingan bisa diminimalisasi. Kemudian sistem 
dapat membantu dewan juri dalam memberikan nilai kepada para peserta yang sedang bertanding, sehingga perhitungan nilai para peserta bisa dengan mudah terselesaikan dan cepat terlihat hasil akhirnya. Adapun saran untuk penelitian selanjutnya adalah menambahkan menu pembuatan bagan pertandingan agar gambaran suatu kejuaraan dapat terlihat jelas melalui gambar bagan-bagan pertandingan tersebut.

\section{Daftar Pustaka}

[1] R. Ramadhan, H. A. Ahmad, and A. Z. Mansoor, "Translasi Pencak Silat Kedalam Film Animasi (Studi Kasus Film Kung Fu Panda),” J. Vis. Art Des., 2017.

[2] A. Yulio Pratama, Rendra Trilaksana, "Perkembangan Ikatan Pencak Silat Indonesia (Ipsi) Tahun 1948-1973," Avatara, 2018.

[3] A. W. Anting Dien Gristyutawati, Endro Puji Purwono, "PERSEPSI PELAJAR TERHADAP PENCAK SILAT SEBAGAI WARISAN BUDAYA BANGSA SEKOTA SEMARANG TAHUN 2012," Act. J. Phys. Educ. Sport. Heal. Recreat., 2012.

[4] I. Setiawan, "Eksistensi Seni Pencak Silat di Kabupaten Purwakarta (Kajian tentang Strategi Adaptasi)," Patanjala J. Penelit. Sej. dan Budaya, 2011.

[5] S. Ediyono and S. T. Widodo, "Memahami Makna Seni dalam Pencak Silat," Panggung, 2019.

[6] M. Mizanudin, A. Sugiyanto, and Saryanto, "Pencak Silat Sebagai Hasil Budaya Indonesia," Pros. SENASBASA, 2018.

[7] Abdul Kadir, "Pengenalan Sistem Informasi Edisi Revisi," Edisi Revisi. 2014.

[8] Y. I. Maulana, "Perancangan Perangkat Lunak Sistem Informasi Pendataan Guru Dan Sekolah (SINDARU) Pada Dinas Pendidikan Kota Tangerang Selatan," J. Pilar Nusa Mandiri, 2017.

[9] P. Widodo and G. E. Saputra, "Perancangan Website E-Commerce Penjualan Alat Olahraga Pencak Silat," Netw. Secur., 2018.

[10] A. L. Ghozali, K. A. Cahyanto, and D. Anwar, "Implementasi Sistem Pendaftaran Dan Edukasi Pencak Silat Budi Asih Se-Ciayumajakuning Berbasis Website Dengan Framework Codeigniter ( Ci )," J. Ilm. Ilmu Komput., 2019.

[11] S. Qomariah and A. Y. Rangan, "PERBANDINGAN METODE SAW DAN MFEP SISTEM PENDUKUNG KEPUTUSAN PENYELEKSIAN ATLET PENCAK SILAT," Just TI (Jurnal Sains Terap. Teknol. Informasi), 2020.

[12] F. Haris, "Rancang Bangun Panduan Pencak Silat Berbasis Web Mobile (Studi Kasus Persaudaraan Setia Hati)," J. Sains Komput. dan Teknol. Inf., 2020.

[13] R. Susanto and A. D. Andriana, "Perbandingan Model Waterfall Dan Prototyping," Maj. Ilm. UNIKOM, 2016.

[14] A. Suryadi and Y. S. Zulaikhah, "Rancang Bangun Sistem Pengelolaan Arsip Surat Berbasis Web Menggunakan Metode Waterfall," J. Khatulistiwa Inform., 2019.

[15] R. A. Sagita and H. Sugiarto, "Penerapan Metode Waterfall Pada Sistem Informasi Penjualan Furniture Berbasis Web,” Netw. Secur., 2016.

[16] I. I. N. Afifah and Supriyanta, "Sistem Informasi Penjualan Busana Pengantin Pada Tutut Manten Yogyakarta," J. Speed - Sentra Penelit. Eng. dan Edukasi, 2018.

[17] H. Agusvianto, "Sistem Informasi Inventori Gudang Untuk Mengontrol Persediaan Barang Pada Gudang Studi Kasus: PT.Alaisys Sidoarjo," J. Inf. Eng. Educ. Technol., 2017. 
[18] P. R. E. Pande, I. N. T. A. Putra, and N. W. S. Putri, "Rancang Bangun Sistem Informasi Pengajuan Kredit Pada Bumdesa Bersama Santhi Sedana," Telematika, vol. 17, no. 2, p. $171,2020$.

[19] T. S. Jaya, "Pengujian Aplikasi dengan Metode Blackbox Testing Boundary Value Analysis (Studi Kasus: Kantor Digital Politeknik Negeri Lampung)," J. Inform. Pengemb. IT, vol. 3, no. 2, pp. 45-46, 2018.

[20] A. Subagja, "Membangun Aplikasi Web dengan Metode OOP," in Membangun Aplikasi Web dengan Metode OOP, 2018.

[21] S. P. Tahalea, H. Himawan, B. Yuwono, and Mahreni, "PENGEMBANGAN SISTEM IDENTIFIKASI WAKTU TUNGGU KERJA ALUMNI BERBASIS MOBILE PADA FAKULTAS TEKNIK INDUSTRI UPN 'VETERAN' YOGYAKARTA," in PROSIDING INDUSTRIAL ENGINEERING CONFERENCE (IEC) 2020, 2020. 